\title{
A Critical Exploration of the Ideals of Marxist Approach in the Poetic Works of Faiz Ahmed Faiz and Kaifi Azmi
}

Kashaf Nasreen Siddiqui

Research Scholar

Department of Languages (English)

Faculty of Humanities and Social Sciences Integral University

Lucknow, Uttar Pradesh, India

kashafsiddiqui12@gmail.com

Dr. Hafiz Mohammad Arif

Associate Professor of English and Head

Department of Languages (English)

Faculty of Humanities and Social Sciences

Lucknow, Uttar Pradesh, India

arifmohdhafiz@gmail.com

Dr. Mohammad Tariq

Assistant Professor of English, Department of English

JSH PG College

Bareili, UP, India

lkotariqfaraz@gmail.com

\section{Abstract}

This paper aims to objectify Marxist tendencies in the poetry of Faiz Ahmad Faiz and Kaifi Azmi, the illustrious, revolutionary poets of the post-imperial era who have dedicated their 
art to resist against anarchy, tyranny, capitalism and misrule, and to create an utopian society where peace and equality would prevail. The paper is an endeavor to show how Faiz Ahmad Faiz and Kaifi Azmi were influenced by Marxist ideology and how they wanted the world to be a better place. However, these poets belonged to different social, political and cultural contexts. These poets have projected their Marxist utopian vision in reaction to capitalist hegemony in their respective social order. The sufferings and resistance of the oppressed were depicted by them. This paper also discusses the influence of Marxism on Romantic literary attitude and how these poets dropped their romantic approach for resistance. Keywords: Marxism, Capitalism, Resistance, Suffering, Utopia, Faiz and Kaifi Research Methodology

The methodology in this paper has been descriptive, comparative and explanatory. Latest MLA Style has been used for mechanics of writing and documentation of sources in the paper.

Introduction

Marxism is a social, economic and political theory that is named after Karl Marx whose goal was to build a society without class, and which examines how capitalism affects labor, production and economic growth. It promotes the overthrowing of capitalism by a working class revolution and the development of a socialist society. According to Karl Marx, classes in society are the origin of conflict and that societies must be free of classes. Marxism is the theory of downtrodden resistance to capitalism. The main founders of Marxism were Karl Marx and Friedrich Engels. In the Pamphlet 1848, "The Communist Manifesto" written by Friedrich Engels and Karl Marx, Marxism was first made public outlining the philosophy of class-conflict and revolution. The radical attitude of Marxism emphasizes the potential of the marginalized to withstand and change the oppressive system. Marxism aims at organizing a society where the means of production are owned and controlled by the laboring class. 
Marxism is not just about money. It's about power.

Faiz Ahmad Faiz

Faiz was born as Faiz Ahmad Khan in1911 in Sialkot, British India. He was a Marxist revolutionary poet. He was also a teacher, a journalist, a military officer, a broadcaster, and more notable of all, an avowed Marxist- Communist apart from being one of the greatest Urdu poets. In the year 1935, he joined Muhammadan Anglo-Oriental College, Amritsar, working as lecturer where Mahmoud Zafar and Rashid Jahan, who were the pioneers of the All-India Progressive Writers' Movement, made him acquainted with Marxist ideas through the book The Communist Manifesto.

Faiz soon developed and started showing his interest towards Marxism leaving behind romanticism. He changed his ideology and got to be the savior of the poor and down-trodden. His marriage with Alys George proved to be a blessing in disguise. She actively participated in communist politics as she already had joined Communist Party in Britain and was greatly influenced by socialist thoughts. One of the few who shone brightest was Faiz who never compromised his values with his radical poetry that centered on the injustice of military dictatorships and oppressions. He always supported the cause of communism in Pakistan in 1950s and 1960s. He was a man with the flaming words who talked of social equality in his poems. There is a spirit of sympathy and compassion towards the downtrodden section of society. Throughout his life, Faiz "thrived to seek love and justice." (Thokchom Martin Singh, p-2)

Faiz was a daring person who never hesitated from giving revolutionary perspective to his poetry which was the need of the hour. In order to improve the situation, he incited the proletariat to act against the oppressive system. In his poem Dogs, which is a call for revolt, Faiz has used the metaphor of dog to denote working class. He provokes them to rise up and raise voice for their rights. He urges them to fight against their exploitation. If the working 
class unite and fight against injustice, oppression and tyranny of the industrialist, the capitalists will not stand before them. He writes that "This oppressed populace, however if it ever rises in revolt/They would show the haughty ones their place,/Eat up their tormentors alive/And make this world all their own" (Trans. Salil p-167).

Faiz has firm belief that a day will come when reign of the capitalists will be perished. The tyranny of the system will come to an end by the power of the weak, the poor and the helpless underdogs and the power of the people will be established. It is evidently seen in his poem "We Shall See” (Hum Dekhenge).

During Lenin's rule, Russia underwent a great revolution in $20^{\text {th }}$ century. This revolution took place through the workers, peasants and the oppressed masses and then the communist government established in 1917. The purpose of this movement was to abolish capitalism and to give peasants and the workers their rights. The success of the socialist revolution in Russia caught the attention of the oppressed class of India. It provoked their spirits and they started thinking to stand against the capitalists. India began to reverberate in the slogan of economic independence. When the Indians learnt about the views of Russia, they embraced the communist views of Russia in the country. The communist views were present in almost all intellectuals, writers, poets and critics at that time. Faiz Ahmad Faiz was no exception to this. Initially, he started writing like a traditional Urdu romantic poet but the social problems made him so obsessed that he forgot 'Love and Beauty' and felt the pain intensely. The works of Faiz soon had a socialist feeling. Now, revolution became his beloved. Instead of being lost in thoughts of beloved, he started to concentrate on persecution of the poor, tears of helpless, conspiracy of one's own people, labor harassment and other socio political issues. It is evidently seen in his poem To the Rival and Ask me not for Love, $O$ dear like Before where he starts with the theme of love and ends with humanistic-socialistic hue. His love has made him sympathetic: 
But what we have learnt in that love

No one except you will understand

I have learnt humility, learnt to empathise with the poor,

Understood the misery of the oppressed

And felt for myself what sighs and frustration mean (Trans. Salil p-35).

Unlike Mirza Ghalib, Faiz was an overtly optimistic personality. In his case, hope springs eternal. He gives a message of hope through his poetry. In his poetry, there is a glimpse of hope for a luminous dawn after the gloomy night of oppression, struggles and sufferings. He believed that the dawn will emerge that will end capitalism. He struggled yet remained a poet of positivity because he believed that struggle and sufferings will not go in vain. Faiz writes, "Whatever befell us, O evening of separation, was part of the game/But our tears brightened you up all the same". He writes in his poem 'A Few Days More, My Love', "The days of tyranny are however numbered now/Hold on for a while, for now you do not have to suffer for long" (Trans. Salil p-75).

His 'love for women' transformed soon into 'love for humanity'. Faiz was also aware of the fact that love and beauty in life doesn't mean ignoring the hardships and sufferings of fellow human beings. He considered problems as his own. The effects of these perceptions on Faiz began to show in the second part of Naqsh-e-Faryadi, "There are other sorrows too in the world, apart from the sorrows of love/And other joys besides the joys of union" (Trans. Salil, p-71). Faiz writes in his poem "To the Rival",

"The two of us have in common, gifts of love's anguish, So many, that I have lost count of them

But what we have learnt in that love No one except you will understand I have learnt humility, learnt to empathise with the poor, 
Learnt the meaning of helplessness, sorrow and despair (Trans.Salil p-35).

Desire for freedom, Marxist and Communist thoughts made him radical, anti romantic poet. The difficult stages of life during Faiz's time have shown Faiz on a progressive path.

Even prison bars could not capture Faiz's mind. There was a period of dictatorship in Pakistan. All the strict restrictions and strict arrests were imposed by the government due to which he was imprisoned but he did not give up. Revolutionary, Marxist and Communist tendencies were still present in his heart and mind. That is why Faiz has created revolutionary tendencies in his poetry. Dast-e-Saba and Zindan Nama were written in jail. This was the golden period for his literary thoughts. Faiz in an interview says about jail:

"Going to jail, as I have earlier observed, was like falling in love again. Not that the jail was a particularly suitable place to write, only one had a lot of time to think and put one's thoughts in verse"(Herald, 14 July 2019).

In another poem, Faiz writes: "I care not if I stand divested of the pen and the tablet/I have dipped my fingers in the blood of my heart,/What if my lips are sealed, for I have/Put a tongue through my chain in every part"(Trans. Salil p-25).

Faiz's poetry is the voice that has raised the status of humanity and has also liberated the human mind from slavery. He has made his poetry the subject of poor huts, poor houses and broken houses. His poetry became a spokesman for the plight of the oppressed. Faiz wrote: I have learnt humility, learnt to empathise with the poor,/Learnt the meaning of helplessness, sorrow and despair,/Under stood the misery of the oppressed/And felt for myself what sighs and frustration mean (Trans. Salil p-35).

His well-known poem "Speak, Your Lips are Free” completely incarnates the revolutionary movement's spirit. He instigates people to raise their voice against oppression in this poem. "Speak up, for you are free to speak/Speak up, for as yet you are master of your tongue" (Trans. Salil p-55). 


\section{Kaifi Azmi}

Athar Hussain Rizvi, better known by his pseudonym, Kaifi Azmi, was born in 1919 in Azamgarh, India. He was a legendary Indian poet, writer and lyricist. He started out as a Ghazal writer. His first collection of poetry, Jhankar was published in 1943. He gripped the themes of love and passion in his poetry. As he became more involved in writing, he began to write about social problems. Kaifi was a man of resistance. Durig Quit India agitations in 1942, he left his studies and joined the 'Progressive Writers Association' and 'Communist Party', guiding him to set out on the path of public-spirited poetry and becoming a true adherent of Marxism. He was the member of the Leftist Indian People's Theatre Association. In his works, he passionately advocated for the equality of underdogs. For him, poetry was a form of resistance. "For Azmi, who died in Bombay on May 10, poetry was a form of resistance, an articulation of the self's protest against the dominance of stifling orthodoxies and the pathologies of power" (The Hindu, 19 May 2002). He dedicated his whole life to writing poems that summarized the need for political and social reform to impoverished masses of the society. Khurshida Bano in her thesis titled 'Kaifi Azami Shakhsiyat Aur Adabi Khidmat Ka Mutaliya' remarked:

Like Faiz and Sardar Jafri, Kaifi too was flowing soul of progressive poetry. He devoted his entire life in composing poem overviewing the need of social, political revolution, and loyalty to the underprivileged masses of the society and he completely submitted himself in order to fulfill his commitment, ambitions and sharing thought and vision. He beautifully and frankly moulded his revolutionary thought and vision in the style of his poetry. His poetry is the message of progressive ideas and thoughts (p-45).

His poetry is a critique of capitalist culture. His writings were similar to that of Ahmad Faraz and Faiz Ahmad Faiz. Dialectical in vision, he glorifies the struggle of suffering class for social, economic and political justice. His poetry was deeply shaped 
through his Marxist reading of class consciousness. He emphasizes in his poems the oppression of the subordinates and communicates through them a message of the development of a social order by undermining the current one. Khurshida Bano in his thesis titled 'Kaifi Azami Shakhsiyat Aur Adabi Khidmat Ka Mutaliya' points out:

In Kaifi Azmi's poetry, the imagination of revolution is to achieve freedom from serfdom, to fight for the rights of the peasants, labours and downtrodden of the society, to check prevalent evils and exploitations in the social life, to fight against the obstacles and prevalent traditions which play negative role in the development of human lives, to make them realize their strengths, to instill courage, ambition and spirit and perseverance in them. $(\mathrm{p}-52)$

Kaifi was a Marxist poet whose poetry was highly influenced by communist ideals. He was poet and savior of the poor, worked vigorously for downtrodden and, along with his fellow poets, engaged actively in protests and marches, agitating with the workers. He encouraged the workers to stand against the exploiter industrialists. He wrote in one of his poems: Salaam un strike karne wale kaamgaron ko/Lahu peene nahi dete jo ab sarmayadaron ko.(Greetings to the striking workers/They don't let the capitalists drink the blood) (Trans. Me) (p-Azmi 96).

He was committed to the cause of the poor since his early age and did never abandon his ideological commitment of dreaming and creating an egalitarian society. Husain Mir Ali in the book Kaifi Azmi Poems|Nazms writes:

Kaifi and his comrades worked tirelessly, first for independence from colonial rule, and then later for an egalitarian and non-sectarian society, but his dream remains a work in progress. His poem 'Inteshar' ends with a demand: koi to sood chukaaye, koi to zimma le, us inquilaab ka jo aaj tak udhaar sa hai. For Kaifi, the revolution is a debt that is still owed to $\operatorname{him}(\mathrm{p}-29)$. 
Faiz Ahmad Faiz and Kaifi Azmi, who were in high demand at social events, wrote against unfair social, political upheaval. They challenged the demons of injustice, bigotry and exploitation. They were bold enough to speak out what others talked about secretly. They advocated strongly for the marginalized section of society. They shared common ideology of love, selflessness, equality and humanity thus sharing mutual grounds for their friendship. They were great poets of love and revolution and were prominent and enthusiastic voice in support of democratic change. Faiz and Kaifi Azmi have always fought to bring an end to injustice, oppression, tyranny and inequality.

Outcome:

This paper is an endeavor to show how Faiz Ahmad Faiz and Kaifi Azmi were influenced by Marxist ideology and how they wanted the world to be a better place. However, these poets belonged to different social, political and cultural contexts. These poets have projected their Marxist vision in reaction to capitalist hegemony in their respective social order. The sufferings and resistance of the oppressed were depicted by them. This paper also discusses the influence of Marxism on Romantic literary attitude and how these poets dropped their romantic approach for literature.

Conclusion and Suggestion:

Faiz Ahmad Faiz and Kaifi Azmi had an ever-lasting faith in Marxist ideology believing that revolution is the only key to establish an utopian society. They seem to provoke underdogs to raise voice for their rights and fight against their exploitation. Their poems were deeply shaped through their Marxist reading of class consciousness. Acknowledgements:

We are deeply grateful to the Chancellor and Vice Chancellor, Dean, Faculty of Humanities and Social Science, Dean, Faculty of Doctoral Studies and Research for their overall supervision, moral and technical support. We wish to specially thank Professor T. Usmani for 
assigning manuscript communication number: IU/R8D/2021-MCN0001095 to this review article. 


\section{Works Cited}

Salil, Kuldip. Best of Faiz. Delhi: Rajpal and Sons, 2020.

Rehman I A. "Going to Jail was like falling in love again- Faiz Ahmed Faiz.” Herald, 14 July, 2019, (https://herald.dawn.com/news/1153696)

Singh, Thokchom Martin. "Faiz Ahmed Faiz: Of Love and Rebellion.” Literary Herald, Inc. Dec 2016, http://tlhjournal.com/uploads/products/57.thokchommartinsingh article1.pdf

Hoskote Ranjit. "Kaifi Azmi: Symbol of Resistance.” The Hindu, 19 May, 2002, (www.azmikaifi.com/kaifi-azmi-symbol-of-resistance/)

Bano Khurshida. Kaifi Azmi Shakhsiyat Aur Adabi Khidmat ka Mutaliya. Ganpat Sahai P.G. College, 2012.

Azmi, Kaifi. Aaj ke Prasidh Shayar. New Delhi: Rajpal \& Sons, 2018.

Sen, Sudeep and Husain Mir Ali. Kaifi Azmi: Poems|Nazms. New Delhi: Bloomsbury, 2019. Works Consulted

Barry, Peter. Beginning Theory: An Introduction to Literary and Cultural Theory. Delhi: Viva Books, 1995.

Habib, M.A.R. Modern Literary Criticism and Theory. New York: John Wiley and Sons, 2008.

---. Literary Criticism from Plato to the Present. Noida: Wiley India, 2005.

Castle, Gregory. The Blackwell Guide to Literary Theory. New York: Wiley-Blackwell, 2007.

Hashmi, Ali Madeeh. Love and Revolution Faiz Ahmed Faiz. New Delhi: Rupa, 2016.

Ali, Zaheer. Romancing with Revolution: Life and Works of Faiz Ahmed Faiz. Delhi: Aakar Books. 2020. 
Ahmad, Syed Iqbal. Faiz Ahmed Faiz ka Inquilabi Rujhan Aur Hamasr Shuara. Delhi: Educational Publishing House, 2015.

Kiernan, V.G. Poems by Faiz. New Delhi: Oxford University Press, 1971.

Bano Darakshan. Faiz Ahmad Faiz Shakhsiyat Aur Shairi. DCSK PG College, 2006.

Sharma Ritu. Poetry As Protest: A Study Of Selected Poems Of Nirala, Faiz And Pash. Panjab University, 2015.

Bashir Burhan. Discourses Of Revolution And Resistance In Select Poems Of Neruda, Faiz And Samih Al-Qasim. Aligarh Muslim University, 2017.

Islam Misbahul. Social And Political View Of Faiz Ahmad Faiz in the Light of his Poetry. Chhatrapati Shahu Ji Maharaj University, 2008.

Chowdhary Supriya. Islam ideology and nationalism discursive formations of progressive urdu poetry with reference to the works of Ali Sardar Jafri Faiz Ahmed Faiz and Kaifi Azmi. Panjab University, 2016.

Shaikh, Nasrin. Kaifi Azmi: Ek Hama Jehat Fankar. Maharaja Sayajirao University of Baroda, 2012.

Asad, Mohd. Kaifi Azmi Hayat Aur Shaeri. B.B.D.P.G. College Paruiya Asram, 2010. ---. Nuskha Ha-e-Wafa. Delhi: Educational Publishing House, 2013.

Hashmi, Ali Madeeh. Love and Revolution Faiz Ahmed Faiz. New Delhi: Rupa, 2016. Ali, Zaheer. Romancing with Revolution: Life and Works of Faiz Ahmed Faiz. Delhi: Aakar Books, 2020.

Kiernan, V.G. Poems by Faiz. New Delhi: Oxford University Press, 1971.

Ahmad, Syed Iqbal. Faiz Ahmed Faiz ka Inquilabi Rujhan Aur Hamasr Shuara. Delhi: Educational Publishing House, 2015.

Varma, Pavan K. Selected Poems|Kaifi Azmi. Gurgaon: Penguin, 2002. 